\title{
Karakteristik Produksi Kambing Peranakan Etawa Dan Kambing Kacang Pada Sistem Pemeliharaan Berbeda Di Kecamatan Toari, Kabupaten Kolaka
}

\author{
Characteristics of Etawa Crossbreed and Kacang Goat Production in Different Maintenance Systems in \\ Toari District, Kolaka Regency
}

\author{
L. O. Nafiu ${ }^{1}$, M. A. Pagala ${ }^{1^{*}}$, \& S. L. Mogiye ${ }^{1}$ \\ ${ }^{1}$ Fakultas Peternakan Universitas Halu Oleo Kendari, \\ Jl. HEA Mokodompit Kampus Bumi Tridharma UHO Anduonohu, Kendari 93232 \\ *Email koresponden author: amrullah.pagala@uho.ac.id \\ (Received 11-04-2020; Revised 14-05-2020; Accepted 20-06-2020)
}

\begin{abstract}
Toari sub-district has a population of 4,434 head or $18.47 \%$ of the total 24,003 head of the goat population in Kolaka Regency. The purpose of this study was to determine the characteristics of Etawa crossbreed goats and bean goats in different maintenance systems in the Toari District. The population in this study were all breeders of Etawa Peranakan goats and peanut goats in the Toari District with the research sample of Ranomentaa, Rano Jaya, Lakito, and Toari villages. The sampling method was determined by purposive sampling, ie the sample was determined intentionally while the data used were primary and secondary data. Primary data were obtained through interviews of 100 respondents while secondary data were obtained from the District, village, and related government offices. The results showed that the production of Etawa Peranakan goat and PE Goat Production characteristics (body weight, birth type, chest circumference, body length, shoulder height, and pelvic height) General Etawa (PE) goats were higher compared to pea goats both in maintenance intensive, semi-intensive or extensive system.
\end{abstract}

Keywords: Production, Maintenance, Toari.

\section{ABSTRAK}

Kecamatan Toari memiliki populasi kambing berjumlah 4.434 ekor atau mencapai 18,47\% dari total 24.003 ekor populasi kambing di Kabupaten Kolaka. Tujuan dari penelitian ini adalah untuk mengetahui karakteristik produksi kambing peranakan etawa dan kambing kacang pada sistem pemeliharaan berbeda di Kecamatan Toari. Populasi dalam penelitian ini adalah seluruh peternak kambing Peranakan Etawa (PE) dan kambing kacang yang ada di Kecamatan Toari dengan sampel penelitian yaitu desa Ranomentaa, Rano Jaya, Lakito dan Toari. Metode pengambilan sampel ditentukan secara purposive sampling, yakni sampel ditentukan secara sengaja sedangkan data yang digunakan berupa data primer dan sekunder. Data primer diperoleh melalui wawancara sebanyak 100 responden sedangkan data sekunder diperoleh dari pemerintah Kecamatan, desa, dan dinas terkait. Hasil penelitian menunjukkan bahwa produksi kambing Peranakan Etawa (PE) dan Kambing Kacang Karakteristik produksi (bobot badan, tipe kelahiran, lingkar dada, panjang badan, tinggi pundak dan tinggi panggul) Peranakan Etawa (PE) umum lebih tinggi dibandikan dengan kambing kacang baik pada pemeliharaan intensif, semi intensif maupun sistem ekstensif.

Kata Kunci: Produksi, Pemeliharaan, Toari.

\section{PENDAHULUAN}

Populasi kambing di Indonesia terbilang cukup besar dan tersebar luas dengan jenis kambing kacang menempati urutan pertama diikuti jenis kambing lain diantaranya kambing Peranakan Etawa (PE). Walaupun jenis kambing sangat banyak di Indonesia namun dalam pemeliharaannya hanya dapat dibedakan untuk tiga tujuan utama, yakni sebagai penghasil daging (kambing potong), penghasil susu (kambing perah), dan dwiguna (Mulyono dan Sarwono 2008). Produksi utama kambing kacang adalah penghasil daging (Erlangga 2013; Doloksaribu 2005). Kambing Peranakan Etawa (PE) merupakan salah satu kambing perah yang cukup potensial sebagai penyedia protein hewani 
(daging dan susu) (Arief dan Rahim 2007; Widodo 2012 et al.). Produksi susu kambing PE berkisar antara 0,5-0,7 liter/ ekor/hari (Middatul 2010; Zurriyati 2011 et al.). Bobot badan dikategorikan sebagai sifat yang mempunyai nilai tinggi dan sangat baik untuk meningkatkan mutu genetik ternak dengan seleksi individu (Tanius 2003). Ukuran dewasa pada kambing beragam dari $20 \mathrm{Kg}$ pada kambing kacang sampai $100 \mathrm{Kg}$ pada kambing PE (Subandriyo 2004).

Kambing PE telah disilangkan dengan kambing lokal untuk memperoleh individu-individu yang memiliki sejumlah sifat unggul yang dimiliki oleh kedua bangsa tetuanya (Nurgiartiningsih 2011). Produktivitas adalah kemampuan ternak kambing untuk menghasilkan produksi dari tiap periode yang ditentukan. Produktifitas tersebut meliputi jumlah anak lahir/liter size (ekor/kelahiran/tahun), (Sarwono 2007; Tiesnamurti 2003 et al.). Taofik dan Depison (2008) lingkar perut seekor ternak dapat menggambarkan besar kecilnya ukuran alat pencernaan yang dimiliki. Besar kecilnya alat pencernaan menggambarkan kapasitas tampung terhadap makanan yang dikonsumsi. Mahmilia (2007), persentase daya hidup anak cendrung menurun dengan meningkatnya jumlah anak. Persentase daya hidup dengan jumlah anak 1-2 memiliki daya hidup yang lebih baik dibandingkan pada anak kembar tiga. Budiarsana dan Sutama (2001) persentase mortalitas prasapih cenderung meningkat dengan meningkatnya jumlah anak sekelahiran.

Daya hidup prasapih tergantung pada litter size, produksi susu serta kemampuan induk merawat anaknya selama periode menyusui (Setiadi et al. 2001). Kemampuan produksi seekor ternak akan dicapai maksimal apabila kebutuhan nutrisi untuk hidup pokok telah terpenuhi. Faktor lain yang mempengaruhi lingkar perut dengan produksi susu kemungkinan berasal dari kemampuan ternak dalam mencerna pakan, pemberian pakan yang berkualitas dapat menghasilkan produktivitas ternak yang maksimal. Menurut Steve dan Marco (2001) rataan jumlah anak sekelahiran kambing betina yang dipelihara secara tradisional berkisar antara 1,84-2,018 ekor/induk/tahun. Sistem pemeliharaan ternak menurut Rianto dan Purbowati (2009) dibedakan menjadi tiga, yaitu cara pemeliharaan intensif, ekstensif dan semi intensif. Sistem pemeliharaan intensif dilakukan dengan cara menempatkan ternak di dalam kandang dan tidak digembalakan dan sistem semi intensif merupakan kombinasi antara sistem ekstensif dan sistem intensif yaitu dengan cara menggembalakan ternak disiang hari dan dikandangkan pada malam hari (Wodzicka et al. 1993).

\section{MATERI DAN METODE}

Materi yang digunakan dalam penelitian ini adalah induk ternak kambing Peranakan Etawa (PE) dan kambing kacang yang dipelihara oleh masyarakat, baik secara intensif/ semi intensif maupun secara ekstensif. Kemudian peternak kambing Peranakan Etawa (PE) dan kambing kacang di Kecamatan Toari serta kuesioner dan alat pencatatan dan pengukuran yang dipersiapkan saat proses wawancara sebanyak 100 responden dan observasi dilapangan yang tersebar di beberapa desa di Kecamatan Toari yaitu desa Ranomentaa, Rano Jaya, Lakito, dan Toari.
Metode pengambilan sampel ditentukan secara purposive sampling, yakni sampel ditentukan secara sengaja berdasarkan beberapa pertimbangan. Pertimbangan yang diambil adalah pemilihan desa lokasi penelitian yang memiliki populasi ternak kambing terbanyak, terdiri atas dua desa yang mewakili sistem pemeliharaan intensif/semi intensif dan dua desa yang mewakili sistem pemeliharaan ekstensif. Penelitian yang diamati dari karakteristik produksi ternak kambing Peranakan Etawa (PE) dan kambing kacang adalah bobot badan dan ukuran tubuh, jumlah anak per kelahiran, serta daya hidup.

Pengambilan data dilakukan setiap hari. Data pengukuran meliputi bobot badan, lingkar dada, panjang badan, tinggi pundak, dan tinggi pinggul mengacu pada Gunawan et al. (2010). Bobot badan (BB) ditimbang dengan menggunakan dacing (timbangan) dan Lingkar 32 dada diukur melingkari rongga dada (body of sternum) di belakang sendi bahu. Pengukuran dilakukan dengan pita ukur dalam satuan $\mathrm{cm}$. Panjang badan diukur dari jarak garis lurus dari tepi tulang processus spinosus sampai os ischium. Pengukuran dilakukan dengan tongkat ukur dalam satuan $\mathrm{cm}$. Data yang diperoleh selanjutnya diolah menggunakan analisis deskriptif berupa nilai rata-rata mean, ragam, simpangan baku atau standar deviasi dan koefisien variasi (Mattjik dan Sumertajaya 2000).

\section{HASIL DAN PEMBAHASAN}

Bobot badan dikategorikan sebagai sifat yang mempunyai nilai tinggi dan sangat baik untuk meningkatkan mutu genetik ternak dengan seleksi individu (Tanius 2003). Jumlah anak sekelahiran yang tinggi akan mempengaruhi kenaikan populasi. Rata-rata jumlah anak sekelahiran kambing PE pada saat lahir adalah 1,51 $\pm 0,43$ ekor, sedangkan rat-rata jumlah anak sekelahiran pada saat sapih adalah 1,46 $\pm 0,54$ ekor (Suparman 2007). Aspek produksi yang dapat dilihat dalam penelitian ini adalah aspek produksi induk dan aspek produksi anak. Aspek produksi yang dimaksud adalah bobot badan, tipe kelahiran dan daya hidup.

\section{Bobot Badan}

Setiap ternak pada umumnya memiliki perbedaan ukuran bobot badan baik induk maupun anak. Terjadinya perbedaan bobot badan ini disebabkan karena adanya beberapa faktor yang diantaranya adalah bangsa, umur, jenis kelamin, lingkungan dan kualitas pakan. Adapun bobot badan yang dimaksud dalam penelitian ini dapat dilihat pada Tabel 1 .

Tabel 1 menunjukkan bahwa bobot badan induk ternak kambing kacang yang dipelihara secara intensif adalah $40 \pm 5,14$, semi intensif $43 \pm 1,41$ dan ekstensif $46 \pm 4,11$. Sedangkan kambing PE yang dipelihara secara intensif memiliki bobot badan $43 \pm 5,54$, semi intensif $46 \pm 1,96$ dan secara ekstensif $49 \pm 5,93$. Kedua induk bangsa kambing, baik bangsa kambing kacang maupun kambing PE memiliki bobot badan yang tinggi pada sistem pemeliharaan ekstensif yaitu 46 $\pm 4,11$ untuk bangsa kambing kacang dan 49 $\pm 5,93$ untuk kambing PE. Bobot badan anak kambing kacang yang dipelihara pada sistem intensif yaitu $2,3 \pm 1,61$, semi 
Tabel 1. Rata-Rata dan Standar Deviasi Bobot Badan (kg) Kambing Kacang dan Peranakan Etawa (PE) di Kecamatan Toari

\begin{tabular}{lcccc}
\hline $\begin{array}{l}\text { Sistem } \\
\text { Pemeliharan }\end{array}$ & \multicolumn{3}{c}{ Bangsa Kambing } \\
\cline { 2 - 5 } & $\begin{array}{c}\text { Kambing } \\
(\mathrm{KK})\end{array}$ & Kacang & \multicolumn{2}{c}{$\begin{array}{c}\text { Peranakan Etawa } \\
(\mathrm{PE})\end{array}$} \\
\cline { 2 - 5 } & Induk & Anak & Induk & Anak \\
\hline Intensif & $40 \pm 5,14$ & $2,3 \pm 1,61$ & $43 \pm 5,54$ & $3,3 \pm 4,12$ \\
Semi & $43 \pm 1,41$ & $2,3 \pm 1,94$ & $46 \pm 1,96$ & $3,4 \pm 1,13$ \\
Intensif & & & & \\
Ekstensif & $46 \pm 4,11$ & $2,4 \pm 1,89$ & $49 \pm 5,93$ & $3,4 \pm 1,09$ \\
\hline
\end{tabular}

Keterangan: Superskrip berbeda pada kolom menunjukkan perbedaan signifikan $(\mathrm{P}<0,05)$

intensif 2,3 $\pm 1,94$ dan sistem ekstensif $2,4 \pm 1,89$. Sedangkan kambing PE memiliki bobot badan yang lebih berat dibandingkan kambing kacang. Bobot badan anak kambing PE yang dipelihara secara intensif adalah $3,3 \pm 4,12$, semi intensif $3,4 \pm 1,13$ dan ekstensif $3,4 \pm 1,09$. Tingginya bobot badan anak kambing PE memiliki hubungan erat dengan induknya. Dari kedua bangsa kambing, bobot badan yang paling tinggi baik induk maupun anak adalah kambing PE yang dipelihara secara ekstensif. Bobot badan induk adalah $49 \pm 5,93$ dan anak 3,4 $\pm 1,09$. Semakin tinggi pertumbuhan induk maka semakin bagus pula pertumbuhan anak. Sejalan dengan pernyataan Sodiq dan Abidin (2008), faktor yang mempengaruhi kualitas dan produksi ternak kambing antara lain bangsa, genetik, sistim pemeliharaan dan kualitas pakan.

\section{Tipe Kelahiran}

Kemampuan beranak banyak merupakan satu hal yang spesifik dari sifat produksi ternak kambing. Sifat ini merupakan hasil interaksi yang besar antara faktor genotipe dan lingkungan (Iniquez et al. 1993). Produktivitas kambing sangat ditentukan oleh kelahiran anaknya dan semakin banyak jumlah anak yang dilahirkan per kelahiran, maka seekor induk dianggap memiliki produktivitas yang tinggi dalam menghasilkan keturunan (Devendra dan Burns 1994).

Tipe kelahiran kambing kacang dan PE dilokasi penelitian memiliki fariasi, ada yg tipe tunggal, K1 dan K2. Variasi ini menunjukkan bahwa kambing kacang dan kambing PE memiliki sistim beranak yang baik. Tipe beranak kambing kacang yang paling tinggi adalah K1 dengan jumlah $22 \%$ yang dipelihara secara ekstensif. Tingginya tipe kelahiran pada sistem pemeliharaan ekstensif karena didukung dengan supply pakan yang kontinue. Sedangkan tipe beranak kambing PE yang paling tinggi adalah tipe K1 dengan jumlah 53\% yang dipelihara secara intensif.

Tingginya jumlah tipe kelahiran K1 pada kambing $P E$ yang dipelihara secara intensif karena memiliki perhatian khusus baik aspek pakan maupun aspek kesehatannya. Pernyataan ini searah dengan pemahaman Sodiq dan Sumaryadi (2002) bahwa rata-rata jumlah kelahiran untuk kambing kacang dan PE adalah tipe K1 yaitu 2 ekor. Dari kedua bangsa kambing yang dipelihara pada sistim yang berbeda yang memiliki tipe kelahiran yang paling tinggi adalah kambing PE dengan tipe K1 (52\%) yang dipelihara secara intensif. Sedangkan tipe kalahiran yang paling rendah adalah kambing kacang (1\%) yang dipelihara secara ektensif. Untuk lebih jelasnya tipe kelahiran kambing Peranakan Etawa dan Kambing Kacang disajikan pada Tabel 2.

\section{Lingkar Dada}

Untuk mengetahui berapa besar lingkar dapat diukur dengan menggunakan pita ukur. Pengukuran dilakukan pada daerah dada tepat di belakang kaki depan. Pengukuran lingkar dada berguna untuk penaksiran bobot badan dan mengetahui perkembangan organ dalam dengan baik. Adapun lingkar dada ternak kambing yang ada di lokasi penelitian dapat dilihat pada Tabel 3. Lingkar dada kambing PE induk pada pemeliharaan secara ekstensif lebih tinggi $(75 \pm 4,78)$ dibandingkan dengan induk kambing kacang

Tabel 2. Tipe Kelahiran Ternak Kambing Kacang dan Peranakan Etawa di Kecamatan Toari

\begin{tabular}{lcccccc}
\hline Sistem Pemeliharaan & \multicolumn{3}{c}{$\begin{array}{c}\text { Tipe Kelahiran } \\
(\mathrm{KK} \%)\end{array}$} & \multicolumn{3}{c}{$\begin{array}{c}\text { Tipe Kelahiran } \\
(\text { PE } \%)\end{array}$} \\
\cline { 2 - 7 } & Tunggal (\%) & K1 $(\%)$ & K2 $(\%)$ & Tunggal (\%) & K1 (\%) & K2 (\%) \\
\hline Intensif & 5 & 20 & 12 & 8 & 53 & 20 \\
Semi Intensif & 1 & 6 & 1 & 2 & 8 & 2 \\
Ekstensif & 5 & 22 & 18 & 2 & 3 & 2 \\
\hline
\end{tabular}

Keterangan: Superskrip Berbeda Pada Kolom Menunjukkan Perbedaan Sangat Signifikan $(\mathrm{P}<0,01)$

Tabel 3. Rata-Rata dan Standar Deviasi Lingkar Dada Kambing Kacang dan Peranakan Etawa di Kecamatan Toari

\begin{tabular}{lcccc}
\hline Sistem Pemeliharaan & \multicolumn{2}{c}{ Kambing Kacang } & \multicolumn{2}{c}{ Kambing Peranakan Etawa } \\
\cline { 2 - 5 } & \multicolumn{2}{c}{ Lingkar Dada $(\mathrm{cm})$} & Lingkar Dada $(\mathrm{cm})$ \\
\cline { 2 - 5 } & \multicolumn{1}{c}{ Induk } & Anak & Anduk & $37 \pm 7,32$ \\
\hline Intensif & $54 \pm 3,76$ & $26 \pm 7,82$ & $73 \pm 4,39$ & $37 \pm 6,31$ \\
Semi Intensif & $56 \pm 4,66$ & $26 \pm 6,64$ & $75 \pm 3,44$ & $39 \pm 5,60$ \\
Ekstensif & $56 \pm 4,47$ & $26 \pm 5,57$ & $75 \pm 4,78$ & \\
\hline
\end{tabular}

Keterangan: Superskrip Berbeda Pada Kolom Menunjukkan Perbedaan Sangat Signifikan $(\mathrm{P}<0,01)$ 
yang dipelihara secara ekstensif $56 \pm 4,47$. Demikian halnya pada sistim pemeliharaan secara intensif dan semi intensif masing-masing induk kambing PE $73 \pm 4,39$ dan $75 \pm 3,44$. Untuk induk kambing kacang yang dipelihara secara intensif dan ekstensif yaitu $54 \pm 3,76$ dan $56 \pm 4,66$. Ukuran lingkar dada anak kambing kacang lebih kecil dibandingkan dengan kambing PE. Lingkar dada anak kambing kacang yang dipelihara secara intensif yaitu $26 \pm 7,82$, semi intensif $26 \pm 6,64$ dan ekstensif 26 $\pm 5,57$. Sedangkan ukuran lingkar dada kambing PE yang dipelihara secara intensif yaitu $37 \pm 7,32$, semi intensif $37 \pm 6,31$ dan ekstensif $39 \pm 5,60$. Dari kedua bangsa kambing, ukuran lingkar dada induk dan anak yang paling tinggi adalah bangsa kambing PE yang dipelihara secara ekstensif. Besarnya kecilnya ukuran lingkar dada ternak kambing biasanya dipengaruhi oleh sifat genetik dan lingkungan. Diperkuat oleh Basbeth et al. (2015) bahwa faktor genetik dan lingkungan memiliki peran penting, karena meskipun ternak memiliki genetik yang unggul, tetapi tanpa dukungan pemeliharaan dan pemberian pakan yang baik, produksinya tidak akan maksimal.

\section{Panjang Badan}

Untuk pengukuran panjang badan dilakukan dengan menarik panjang dari bagian penonjolan tulang bahu sampai penonjolan tulang panggul atau diukur dari pangkal tulang panggul sampai pangkal tulang leher. Ukuran panjang badan dalam penelitian ini dapat dilihat pada Tabel 4 .

Tabel 4. Rata-Rata dan Standar Deviasi Panjang Badan Kambing Kacang dan Peranakan Etawa di Kecamatan Toari

\begin{tabular}{lcccc}
\hline \multirow{2}{*}{$\begin{array}{l}\text { Sistem } \\
\text { Pemeliharaan }\end{array}$} & \multicolumn{2}{c}{ Kambing Kacang } & \multicolumn{2}{c}{$\begin{array}{c}\text { Kambing Peranakan } \\
\text { Etawa }\end{array}$} \\
\cline { 2 - 5 } & \multicolumn{2}{c}{ Panjang Badan $(\mathrm{cm})$} & \multicolumn{2}{c}{ Panjang Badan $(\mathrm{cm})$} \\
& Induk & Anak & Induk & Anak \\
\hline Intensif & $55 \pm 6,04$ & $39 \pm 6,91$ & $74 \pm 8,82$ & $51 \pm 7,46$ \\
Semi Intensif & $55 \pm 4,08$ & $40 \pm 5,60$ & $74 \pm 3,90$ & $51 \pm 4,67$ \\
Ekstensif & $56 \pm 5,51$ & $40 \pm 4,65$ & $75 \pm 3,61$ & $52 \pm 7,37$ \\
\hline
\end{tabular}

Keterangan: Superskrip Berbeda Pada Kolom Menunjukkan Perbedaan Sangat Signifikan $(\mathrm{P}<0,01)$

Ukuran panjang badan induk ternak kambing kacang yang dipelihara secara ekstensif $(55 \pm 6,04)$ lebih kecil dibandingkan dengan panjang badang kambing PE yang dipelihara secara ekstensif $(75 \pm 3,61)$. Demikian halnya dengan panjang badan kambing kacang yang dipelihara secara intensif dan semi intensif masing-masing 55 $\pm 6,04$, semi intensif $55 \pm 4,08$. Ukuran panjang badan kambing PE yang dipelihara secara intensif yaitu $(74 \pm 8,82)$ semi intensif $(4 \pm 3,90)$. Dari kedua ukuran panjang badan induk yang paling tinggi adalah bangsa kambing PE yang dipelihara secara ekstensif. Anak kambing kacang yang dipelihara secara intensif memiliki ukuran panjang badan $39 \pm 6,91$, semi intensif $40 \pm 5,60$ dan ekstensif $40 \pm 4,65$. Sedang bangsa kambing PE memiliki ukuran badan yang panjang dibandingkan dengan kambing kacang. Ukuran anak kambing PE yang dipelihara secara intensif memiliki panjang badan $51 \pm 7,46$, semi intensif $51 \pm 4,67$ dan ektensif
52 $\pm 7,37$. Anak kambing PE yang dipelihara secara ekstensif memiliki ukuran badan yang panjang dibandingkan dengan kambing kacang karena konsumsi pakannya lebih besar. Dipertegas oleh Simanihuruk et al. (2006) rendahnya karakteristik penggunaan pakan memberikan dampak terhadap pertambahan bobot badan yang rendah, hal ini karena ternak dikandangkan dengan hijauan yang ditentukan tidak mendapat kebebasan memilih hijauan untuk dikonsumsi sehingga kebutuhan kambing untuk pertumbuhan belum mencukupi.

\section{Tinggi Pundak}

Tinggi pundak diukur dengan tongkat ukur dari permukaan tanah sampai bagian pundak tepat dibelakang kaki depan. Dalam pengukuran tinggi pundak ini posisi kaki kambing harus berbentuk segi empat dan lurus. Kambing harus ditempatkan di tempat yang datar dan cara berdiri sangat mempengaruhi terhadap hasil pengukuran. Tinggi pundak ternak kambing dapat dilihat pada Tabel 5.

Dari kedua bangsa kambing baik kambing kacang maupun kambing PE memiliki tinggi pundak yang berbeda. Tinggi pundak ternak kambing kacang yang dipelihara secara intensif, semi intensif dan ekstensif memiliki ukuran yang kecil dibandingkan dengan kambing PE. Tinggi pundak induk kambing kacang yang dipelihara secara intensif yaitu $57 \pm 5,76$, semi intensif $57 \pm 5,54$ dan ekstensif $57 \pm 6,58$ lebih kecil dibandingkan dengan bangsa kambing PE yang dipelihara secara intensif $(65 \pm 6,65)$, semi intensif $(65 \pm 6,83)$ dan secara ekstensif $(67 \pm 7,21)$. Semakin tinggi pundak ternak kambing maka semakin menunjukkan bahwa ternak tersebut memiliki bobot badan dan memiliki konsumsi pakan yang baik.

Tinggi pundak anak akan mengikuti bentuk tubuh induknya. Semakin baik aspek produksi induk maka semakin baik pula produksi anaknya. Pernyataan ini dapat dilihat dari hasil analisis bahwa tinggi pundak anak kambing kacang yang dipelihara secara intensif yaitu $31 \pm 5,28$, semi intensif $31 \pm 5,32$ dan secara ekstensif $32 \pm 7,46$. Ukuran pundak kambing kacang lebih kecil dibandingkan dengan kambing PE. Tinggi pundak anak kambing PE yang dipelihara secara intensif yaitu $38 \pm 7,48$, semi intensif $38 \pm 6,40$ dan ekstensif $38 \pm 6,85$. Tinggi pundak kambing PE lebih tinggi dibandingkan kambing kacang baik induk maupun anak yang dipelihara secara intensif, semi intensif maupun ekstensif.

Tabel 5. Rata-Rata dan Standar Deviasi Tinggi Pundak Kambing Kacang dan Peranakan Etawa di Kecamatan Toari

\begin{tabular}{lcccc}
\hline \multirow{2}{*}{$\begin{array}{l}\text { Sistem } \\
\text { Pemeliharaan }\end{array}$} & \multicolumn{2}{c}{ Kambing Kacang } & \multicolumn{2}{c}{$\begin{array}{c}\text { Kambing Peranakan } \\
\text { Etawa }\end{array}$} \\
\cline { 2 - 5 } & \multicolumn{2}{c}{ Tinggi Pundak $(\mathrm{cm})$} & \multicolumn{2}{c}{ Tinggi Pundak $(\mathrm{cm})$} \\
\cline { 2 - 5 } & Induk & Anak & Induk & Anak \\
\hline Intensif & $57 \pm 5,76$ & $31 \pm 5,28$ & $65 \pm 6,65$ & $38 \pm 7,48$ \\
Semi Intensif & $57 \pm 5,54$ & $31 \pm 5,32$ & $65 \pm 6,83$ & $38 \pm 6,40$ \\
Ekstensif & $57 \pm 6,58$ & $32 \pm 7,46$ & $67 \pm 7,21$ & $38 \pm 6,85$ \\
\hline
\end{tabular}

Keterangan: Superskrip Berbeda Pada Kolom Menunjukkan Perbedaan Sangat Signifikan $(\mathrm{P}<0,01)$ 
Tabel 6. Rata-Rata dan Standar Deviasi Tinggi Panggul Kambing Kacang dan Peranakan Etawa di Kecamatan Toari

\begin{tabular}{lcccc}
\hline $\begin{array}{l}\text { Sistem } \\
\text { Pemeliharaan }\end{array}$ & \multicolumn{2}{c}{ Kambing Kacang } & \multicolumn{2}{c}{$\begin{array}{c}\text { Kambing Peranakan } \\
\text { Etawa }\end{array}$} \\
\cline { 2 - 5 } & \multicolumn{2}{c}{ Tinggi Panggul $(\mathrm{cm})$} & \multicolumn{2}{c}{ Tinggi Panggul $(\mathrm{cm})$} \\
\cline { 2 - 5 } & Induk & Anak & Induk & Anak \\
\hline Intensif & $55 \pm 6,05$ & $31 \pm 4,83$ & $64 \pm 7,88$ & $36 \pm 7,69$ \\
Semi Intensif & $55 \pm 5,57$ & $31 \pm 4,29$ & $64 \pm 5,99$ & $36 \pm 4,55$ \\
Ekstensif & $55 \pm 4,82$ & $32 \pm 5,91$ & $64 \pm 5,89$ & $36 \pm 6,42$ \\
\hline
\end{tabular}

Keterangan: Superskrip berbeda pada kolom menunjukkan perbedaan signifikan $(\mathrm{P}<0,05)$

\section{Tinggi Panggul}

Untuk mengukur tinggi punggung dilakukan dengan melihat jarak tegak lurus dari taju duri ruas tulang punggung terakhir sampai ke tanah. Titik ini dapat dilakukan dengan menarik garis tegak lurus tepat diatas pangkal tulang rusuk terakhir. Tinggi panggul di lokasi penelitian dapat dilihat pada Tabel 6. Berdasarkan Tabel 6 menunjukkan bahwa tinggi panggul induk ternak kambing kacang lebih rendah dibandingkan dengan tinggi panggul kambing PE. Induk kambing kacang memiliki tinggi panggul yang dipelihara secara intensif $(55 \pm 6,05)$, semi intensif $(55 \pm 5,57)$ dan ekstensif $(55 \pm 4,82)$ sedangkan kambing PE memiliki ukuran tinggi panggul yang dipelihara secara intensif $(64 \pm 7,88)$, semi intensif $(64 \pm 5,99)$ dan ekstensif $(64 \pm 5,89)$. Tinggi pundak induk kambing kacang dan kambing PE akan memberikan gambaran terhadap tinggi pundak anak. Tingginya pundak anak kambing kacang yang dipelihara secara intensif $(31 \pm 4,83)$, semi intensif $(31 \pm 4,29)$ dan ekstensif $(32 \pm 5,91)$ lebih kecil dibandingkan dengan ukuran tinggi pundak kambing PE yang dipelihara secara intensif $(36 \pm 7.69)$, semi intensif $(36 \pm 4,55)$ dan ekstensif $(36 \pm 6,42)$.

\section{KESIMPULAN}

Karakteristik produksi (bobot badan, tipe kelahiran, lingkar dada, panjang badan, tinggi pundak dan tinggi panggul) kambing PE umum lebih tinggi dibandikan dengan kambing kacang baik pada pemeliharaan intensif, semi intensif maupun sistem ekstensif. Sistem pemeliharaan ekstensif menghasilkan karaktersitif produksi kambing PE dan kambing kacang yang lebih tinggi, selanjutnya sistem pemeliharaan semi intensif dan paling rendah pada sistem intensif.

\section{DAFTAR PUSTAKA}

Arief, \& F. Rahim. 2007. Hubungan Bobot Badan, Lingkar Ambing, dan Umur Induk Terhadap Produksi Susu Sapi Fries Holland di Kelompok Tani Permata Ibu Padang. Universitas Andalas Padang.

Basbeth, A. H., W. S. Dilaga, \& A. Purnomoadi. 2015. Hubungan antara ukuran-ukuran tubuh terhadap bobot badan kambing jawarandu jantan umur muda di Kabupaten Kendal Jawa Tengah. Animal Agriculture Journal. 4(1):35-40.
Budiarsana, I. G. M., \& I. K. Sutama. 2001. Efisiensi Produksi Susu Kambing Peranakan Etawa. Seminar Nasional Teknologi Peternakan dan Veteriner. Balai PenelitianTernak, Bogor.

Davendra, C., \& M. Burn. 1994. Produksi kambing di daerah tropis. Institut Teknologi Bandung, Bandung. (Diterjemahkan oleh I. D. K. H. Putra).

Doloksaribu, M. 2005. Produktivitas Kambing Kacang pada Kondisi Dikandangkan :Bobot Lahir, Bobot Sapih, Jumlah Anak Sekelahiran Dan Daya Hidup Anak Prasapih. Prosiding Seminar Nasional Teknologi Peternakan dan Veteriner.581. Loka Penelitian Kambing Potong, Galang Sungei Putih, Deli Serdang.

Erlangga, B. A. Nasich, M. Nugroho, \& Kuswati. 2013. Kacang Goats Doe Productivity in Kedungadem SubDistrict Bojonegoro Regency. Universitas Brawijaya. Malang.

Gunawan, A., R. H. Mulyono, C. Sumantri. 2010. Identifikasi ukuran tubuh domba garut tipe tangkas, tipe pedaging, dan persilangannya melalui pendekatan analisis komponen utama. Anim. Production. 11(1):814.

Iniquez, L., W. A. Pattie, \& B. Gunawan. 1993. Sifatsifat produksi yang ditentukan oleh banyak gen. Dalam: Produksi Kambing dan Domba di Indonesia. M. Wodzickatomaszewka,; I Ketut Sutama; I Gede Putu dan Thamrin D. Chaniago (Eds.). Sebelas Maret University Press, Surakarta. hlm. $111-117$.

Mahmilia, F. 2007. Penampilan Reproduksi Kambing Induk: Boer dan Kacang yang Disilangkan dengan Pejantan Boer. Prosiding Seminar Nasional Teknologi Peternakan dan Veteriner 2007: 485-490.

Mattjik, A. A., I. M. Sumertajaya. 2000. Perancangan Percobaan dengan Aplikasi SAS dan Minitab Jilid 1. Bogor (ID): IPB Press.

Middatul, S. 2010. Performans Reproduksi Ternak Kambing PE (Peranakan Etawa) di PT. Reanindo Perkasa Kenagarian Barulak Kecamatan Tanjung Baru Kabupaten Tanah Datar.

Mulyono, \& Sarwono. 2008. Teknik Pembibitan Kambing dan Domba. Penebar Swadaya. Jakarta.

Nurgiartiningsih, V. M. A. 2011. Evaluasi genetik pejantan Boer berdasarkan performans hasil persilangannya dengan kambing lokal. Jurnal Ternak Tropika 2011. 12(1):82-88.

Riyanto, E., \& E. Purbowati. 2009. Panduan Lengkap Sapi Potong. Jakarta (ID): Penebar Swadaya.

Sarwono, B. 2007. Beternak Kambing Unggul. Jakarta (ID): Penebar Swadaya.

Setiadi, B. Subandriyo, M. Martawidjaja, I. K. Sutama, D. Yulistiani, \& D. Priyanto. 2001. Evaluasi Keungulan Produktivitas dan Pemantapan Kambing Persilangan. Kumpulan Hasil-Hasil Penelitian Peternakan APBN Tahun Anggaran 2001. Balai Penelitian Ternak, Ciawi, Bogor. Pp 123-142.

Sodiq, A., \& Z. Abidin. 2008. Kambing Peranakan Etawa Penghasil Susu. Agromedia Pustaka. Jakarta.

Sodiq, A., \& M. Y. Sumaryadi. 2002. Reproductive Performance of kacang and Peranakan Etawa Goat in 
Indonesia, J. Animal Production. 52-59.

Simanihuruk, K., K. G. Wiryawan, \& S. P. Ginting. 2006. Pengaruh taraf kulit buah markisa (Passiflora edulis Sims f. edulis Deg) sebagai campuran pakan kambing Kacang: I. konsumsi, kecernaan dan retensi nitrogen. JITV. 11: 97-105.

Subandriyo. 2004. Strategi Pemanfaatan Plasma Nutfah Kambing Lokal dan Peningkatan Mutu Genetik Kambing di Indonesia. Makalah Seminar 5 Agustus. Balitvet. Bogor.

Suparman. 2007. Beternak Kambing. Jakarta (ID): Azka Press.

Steve, D.C. \& F. B. Marco. 2001. Reproductive Success in Female Mountain Goats: The Influence of Age and Social Rank. Anim. Behavior. 62:173-181.

Tanius, T.S.A. 2003. Beternak Kambing Perah Peranakan Etawa. Press, Surakarta.

Tiesnamurti, B., I. Inounu, Subandriyo, \& H. Martojo. 2003. Kapasitas produksi susu domba priangan peridi : II. Kurva laktasi. JITV. 8(1):17-25.
Taofik, A., \& Depison. 2008. Hubungan antara lingkar perut dan volume ambing dengan kemampuan produksi susu kambing Peranakan Ettawa. Jurnal Ilmiah Ilmu-Ilmu Peternakan. 11(2):59-74.

Widodo, V., R. Afina, \& I. G. S. Budisatria. 2012. Produksi dan evaluasi kualitas susu bubuk asal kambing Peranakan Etawa (PE). J. Teknol. dan Industri Pangan. 23(2):132-139.

Wodzicka, I. M. Mashka, A. Djajanegara, S. Gardiner, \& T. P. Wiradaya. 1993. Produksi Kambing dan Domba di Indonesia. Surakarta (ID): Sebelas Maret University Press.

Zurriyati, Y., R. R. Noor, \& R. R. A. Maheswari. 2011. Analisis molekuler genotipe kappa kasein (K-Kasein) dan komposisi susu kambing Peranakan Etawah, Saanen dan Persilangannya. JITV. 16(1):61-70. 